\title{
Ortaokul Öğrencilerinin Bilgilendirici Metin Yazma Becerilerinin İncelenmesi
}

\section{The Analysis of Secondary School Students' Informative Writing Skills}

\author{
Merve Müldür, ${ }^{\mathrm{a}^{*}}$ Arzu Çevik ${ }^{\mathrm{b}}$ \\ ${ }^{a}$ Dr. Öğr. Üyesi, Süleyman Demirel Üniversitesi, Eğitim Fakültesi, Türkçe ve Sosyal Bilimler Eğitimi Bölümü, 32000, Isparta/Türkiye. \\ ORCID: 0000-0002-2595-5749

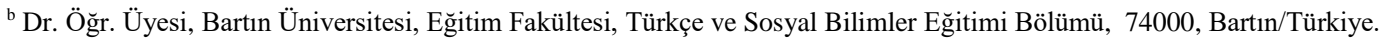 \\ ORCID: 0000-0001-9673-847X
}

\section{MAKALE BİLGİSI}

\section{Makale Geçmişi:}

Başvuru tarihi: 01 Şubat 2019

Düzeltme tarihi: 09 Mart 2019

Kabul tarihi: 27 Mart 2019

\section{Anahtar Kelimeler:}

Bilgilendirici (açıklayıcı) metin

Yazma becerisi

Ortaokul öğrencileri

\section{ARTICLE INFO}

\section{Article history:}

Received 01 February 2019

Received in revised form 09 March 2019

Accepted 27 March 2019

\section{Keywords:}

Informative (expository) texts

Writing skill

Secondary school students
ÖZ

Bu araştırmanın amacı ortaokul öğrencilerinin bilgilendirici metin (açıklayıcı) yazma düzeylerini belirlemektir. Araştırmada nicel araştırma yöntemlerinden betimsel tarama modeli kullanılmıştır. Araştırmanın çalışma grubunu 2015-2016 eğitim öğretim yılı II. yarıyılında öğrenim gören 411 ortaokul öğrencisi oluşturmaktadır. Öğrencilere farklı yapılarda bilgilendirici metinler üretebilecekleri konular verilerek bu konulardan herhangi biri ile ilgili bir metin yazmaları istenmiştir. Öğrenci metinleri "Bilgilendirici Metin Yazma Değerlendirme Formu" kullanılarak puanlanmıştır. Verilerin değerlendirilmesinde betimsel istatistik, bağımsız örneklemler t-tesi, tek yönlü varyans analizi ve Dunnett $\mathrm{C}$ testi kullanılmıştır. Araştırma sonucunda öğrencilerin bilgilendirici (açıklayıcı) metin yazma becerilerinin yetersiz düzeyde olduğu tespit edilmiştir. Ayrıca öğrencilerin bilgilendirici (açılayıcı) yazma becerilerinin cinsiyet ve sınıf düzeyine göre de anlamlı farklılık gösterdiği bulunmuştur.

\begin{abstract}
A B S T R ACT
The aim of the present study is to identify informative (expository) text writing levels of secondary school students. Descriptive survey model which is a quantitative research model is used in this study. The study group consists of 411 students studying at a secondary school in Isparta in the second semester of 2015-2016 academic year. The students are provided with topics which they can produce informative texts in different stuructures and then they are asked to write a text on any of these topics. Student texts are scored via Informative Writing Evaluation Form. Descriptive statistics, the independent samples t-test, one way ANOVA and Dunnett $\mathrm{C}$ test are used for the data analysis. According to the study results, it is found out that students' informative (expository) writing skills are at an insufficient level. In addition, it is revealed that students' informative (expository) writing skills differ significantly in terms of gender and grade.
\end{abstract}

\section{Giriş}

Okuma ve dinlemenin metinden anlam çıkarma, konuşma ve yazmanın da metin üretme süreci olduğu göz önünde bulundurulduğunda metinlerin ana dili eğitiminde önem taşıdığı söylenebilir. Okullarda en sık kullanılan materyal olması yönüyle önem taşıyan metinlerin dil becerilerinin geliştirilmesinde de tartışılmaz bir önemi mevcuttur (Temizyürek, 2008). Bir metni yapılandırma sürecinde görev yüklenen olguların çeşitliliği ve birbiri arasındaki karmaşık ilişki ağı nedeniyle metin kavramına ilişkin çeşitli tanımlar ortaya çıkmakla birlikte (Ülper, 2011) metin en yaygın tanımlardan biriyle "Bildirişim değeri taşıyan, eyleme yönelik devingen bir bütündür. Kısaca metin, başı ve sonu kapalı yapı oluşturan dilsel göstergelerin art arda geldiği anlamlı bir yapıdır" (Günay, 2007, s. 55).

İlgili literatür incelendiğinde metin kavramının yanı sıra metinlerin tür ve yapı tasnifinde de çeşitlilik (De Beaugrande ve Dressler, 1981; Günay, 2007; Kıran ve Eziler Kıran, 2003; Tansel, 1978) dikkati çekmektedir. Söz konusu

\footnotetext{
* Sorumlu yazar/Corresponding author

e-posta: mervemuldur@sdu.edu.tr
} 
kaynaklar incelendiğinde metinlerin sınıflandırılmasındaki çeşitliliğinin metne bakış açısındaki çeşitlilikle ve metinlerin tip, tür, söylem, yapı gibi farklı terimlerle sınıflandırılmasıyla ilişkili olduğu söylenebilir. Metinlerin sınıflandırılmasında metin yapılarını ön plana çıkaran araştırmacılar (Akyol, 2010; Coşkun, 2013; Güneş, 2007) da mevcut olup okullarımızda Türkçe Dersi Öğretimi Programı (MEB, 2018) kapsamında benzer bir yaklaşımla metinler bilgilendirici, öyküleyici ve şiir olmak üzere üç başlık altında ele alınmakta, bu tasnife uygun bir şekilde eğitim verilmeye çalışılmaktadır. Bunlardan özellikle öyküleyici ve bilgilendirici metinler öğrencilerin okul hayatlarında en yaygın olarak kullandıkları metinlerdir.

Söz konusu tasnifin alt sinıflandırmalarından birini oluşturan, okuyucuya bir konu hakkında bilgi vermek veya bir şeyi açıklamak amacıyla yazılan bilgilendirici metinler alan yazında açıklayıcı metinler olarak da anılmaktadır (Piccolo, 1987; Tompkins, 2000; Warriner, 1992). Bilgilendirici (açıklayıcı) metinlerin metindeki bilgilerin düzenlenişi açısından farklı yapıları bulunmaktadır. Alan yazında konuyla ilgili çalışmalar yapan araştırmacıların (Akyol, 1999, 2010; Armbruster, Anderson ve Ostertag, 1987; Bohaty, 2015; Coşkun, 2013; Englert ve Hiebert, 1984; Hall, Sabey ve McClellan, 2005; McGee ve Richgels, 1985; Özmen, 2011; Tompkins, 2000) çalışmalarında yaygın olarak Meyer'in (Meyer, 1975; Meyer ve Freedle, 1984) sınıflandırılmasından yararlanarak bilgilendirici (açıklayıcı) metinleri beş başlık altında ele aldıkları görülmektedir. $\mathrm{Bu}$ sınıflandırmaya göre de bilgilendirici (açıklayıcı) metinler; sıralama, tanımlama, problem çözme, neden-sonuç, karşılaştırma olmak üzere beş başlık altında toplanmaktadır.

Okuldaki, iş yerindeki ve toplumdaki başarımız bu tür metinleri anlama ve anlatma becerimize dayanmakta; bilgilendirici okuryazarlık başarının merkezinde yer almaktadır. Eğitimin temel amacı, bu tür metinleri okuyup anlayabilen, eleştirebilen ve edindiği bilgilerle iletişim kurabilen bireyler yetiştirmektir (Duke, 2000, 2004). Özellikle okuldaki akademik faaliyetlerin pek çoğu öğrencilerin açıklayıcı nitelikte materyaller üretmelerini gerekli k1lmaktadır (Thomas, Englert ve Gregg, 1987). Bilgilendirici metinlerin ilkokulun ilk yıllarından itibaren etkin kullanımını sağlamak, çocukların dünyada bilgisinin gelişmesini ve bilgi çağında başarı için gerekli olan önemli becerilerin teminini sağlayabilir (Hall ve Sabey, 2007). Bu metinleri anlama ve yazma okuldaki başarı için zaruridir (Taylor ve Beach, 1984). Görüldüğü üzere günümüz bilgi toplumundaki başarı bu metinleri anlayabilme ve bu yapıda metinler üretmeye dayanmaktadır.

Hayatın pek çok alanında bilgilendirici okuryazarlık önemli olmakla birlikte bilgilendirici (açıklayıcı) metinleri anlamak ve bu yapıda metinler üretmek özellikle öyküleyici metinlerle kıyaslandığında öğrencilere zor gelmektedir. Farklı araştırmalarda öğrencilerin bu tür metinleri anlama konusunda öyküleyici metinlere kıyasla daha çok zorlandıkları ortaya çıkarılmış veya vurgulanmıştır (Best, Floyd ve McNamara, 2008; Şahin, 2013; Temizyürek, 2008; Yıldırım, Yıldız, Ateş ve Rasinski, 2010). Mevcut araştırmanın sınırlarını oluşturan yazma açısından da benzer bir durum söz konusudur. Yazma becerisinde de öğrencilerin öyküleyici metinlere kıyasla bilgilendirici metinleri yazma konusunda zorlandıklarını gösteren araştırmalar mevcuttur
(Hall-Mills ve Apel, 2012; Sallabaş, 2007; Taylor ve Beach, 1984).

Açıklayıcı metinlerin öğrencilere zor gelmesinin, öğrencilerin bu yapıdaki metinleri anlama ve metinler üretmede zorlanmalarının altında türlü sebepler yatmaktadır. Bunlardan biri öğrencilerin öyküleyici metin türleriyle erken yaşlarda karşılaşırken bilgilendirici metinlerle daha geç yaş dönemlerinde karşılaşmalarıdır. Öğrenciler yazılı dildeki öyküleyici söylem kullanımı ve farkındalığı, hikâye anlatımı deneyimleri yoluyla yaşamın erken dönemlerinde gelişmeye başlamakta iken (Nelson, Bahr ve Van Meter, 2004) bu metinlerle erken yaşlarda karşılaşmamaktadır (Duke, 2000). Ayrıca çocukların bilişsel gelişim ve deneyimleri, iyi yazılmış bilgilendirici metinlerin azlığı, öğrencilerin okul yaşamlarında da bu metinlere sınırlı düzeyde maruz kalmaları ve öğretmenlerin öğrencileri bu metinler konusunda nasıl yönlendireceğini bilememesi (Hall vd., 2005) gibi hususlar da bu metinlerde öğrencilerin zorlanma nedenleri arasında sayılabilir. Bunların ötesinde bilgilendirici metinlerin kendisinden kaynaklı da birtakım sorunlar da mevcuttur. Bilgilendirici metinlerin farklı yapılardan oluşması, bu yapıdaki metinlerde öyküleyici metinlerdeki gibi basit, sıralı olayların olmaması, mantıki ilişkilerin fazla olması (Williams, 2005), öğrencilerin bu metinleri anlama ve üretmede kullanılan metin organizasyonu hakkında gerekli ön bilgiye sahip olmaması (Taylor \& Beach, 1984) ve metin yapısı farkındalığının olmaması (Armbruster vd., 1987) da öğrencilerin bu metinlerde zorlanmalarına sebep olabilmektedir. Söz konusu bu hususlar, sadece öğrencilerin bu yapıdaki metinleri anlamalarını zorlaştırabilecek hususlar olmayıp onların bu yapıda metinler üretebilmelerinde de engel teşkil edebildiğini göstermektedir.

\section{Araştırmanın Problemi ve Amacı}

\subsection{Araştırmanın Problemi}

İlgili literatür bağlamında da görüldüğü gibi türlü gerekçeler sebebiyle bilgilendirici metinler, öyküleyici metinlere göre öğrencilerin gerek anlama gerek üretim konusunda zorlandıkları; akademik, sosyal vb. pek çok açıdan önemli olmasına rağmen son derece ihmal edilen metinlerdir. Mevcut araştırmanın sınırlarını oluşturan yazma becerisi ve ortaokul öğrencilerinin durumu açısından da bakıldığında benzeri bir durum söz konusudur. Ülkemizde ortaokul öğrencilerinin yazma becerilerinin tespitine ilişkin yapılan çalışmaların daha çok öyküleyici metin yapısı odaklı olduğu görülmektedir (Ar1, 2008; Coşkun, 2005; Çeçen, 2011; Çoban, 2010; İpek Eğilmez ve Berber, 2017; Kaynaş, 2014; Kılıç, 2012; Yaylacık, 2014; Yılmaz, 2008). Sınırlı sayıda çalışmada (Çelik, 2010; Sallabaş, 2007; Ülper, 2011) bilgilendirici (açıklayıcı) metinlere odaklanıldığı görülmektedir. Bu çalışmalarda belirli bir sınıf kademesine odaklanıldığı ve ortaokul öğrencilerinin bütün kademelerini kapsayan bir çalışma yapılmadığı dikkati çekmektedir. Mevcut araştırmada ortaokul öğrencilerin bilgilendirici yazma becerilerinin durumu tespit edilerek söz konusu durumun sınıf seviyesi, cinsiyet değişkenlerine göre değişip değişmediği incelenmiştir. $\mathrm{Bu}$ çalışmanın her sınıf kademesindeki öğrencileri kapsayacak şekilde bir değerlendirmeye gidilmesi yoluyla Türkçe literatüre katkı sağlayacağı düşünülmektedir. 


\subsection{Araştırmanın Amacı}

$\mathrm{Bu}$ araştırmanın temel amacı, ortaokul öğrencilerinin bilgilendirici yazma düzeyini tespit etmek ve çeşitli değişkenler açısından incelemektir. Bu çerçevede aşağıdaki sorulara yanıt aranmıştır:

(i) Araştırmaya katılan öğrencilerin bilgilendirici (açıklayıcı) metin yazma becerileri ne düzeydedir?

(ii) Araştırmaya katılan öğrencilerin bilgilendirici (açıklayıcı) metin yazma becerileri cinsiyete göre anlamlı bir farklılık göstermekte midir?

(iii) Araştırmaya katılan öğrencilerin bilgilendirici (açıklayıcı) metin yazma becerileri sınıf seviyesine göre anlamlı bir farklılık göstermekte midir?

\section{Yöntem}

\subsection{Araştırma Modeli}

Ortaokul öğrencilerinin bilgilendirici (açıklayıcı) yazma durumlarını tespit etmeyi ve çeşitli değişkenler açısından incelemeyi amaçlayan bu çalı̧̧mada nicel araştırma yöntemlerinden tarama modeli kullanılmıştır. Tarama modelinde geçmişte veya hâlen var olan bir durum, var olduğu şekli ile betimlenir (Karasar, 2008). Çalışmada var olan bir durumun (ortaokul öğrencilerinin bilgilendirici yazma düzeyleri) betimlenmesi ve bazı değişkenler açısından incelenmesi amaçlandığından araştırma, tarama modeli ile desenlenmiştir.

\subsection{Evren ve Örneklem}

Araştırmanın evrenini 2015-2016 eğitim öğretim yılının ikinci döneminde Isparta ilinde öğrenim gören 23052 öğrenci oluşturmaktadır (MEB 2016, s. 40). Araştırma kapsamında örneklem belirlenirken küme örnekleme yöntemi kullanılmıştır (Karasar, 2008, s. 114). 25000 kişiik evren büyüklügüne sahip bir araştırma için (.95 güvenirlik düzeyinde) gerekli örneklem sayısı 378'dir (Can, 2017, s. 30). Buna göre Isparta İl Millî Eğitim Müdürlüğünden bilgi alınarak Isparta'da alt, üst ve orta düzeyde sosyoekonomik düzeyi temsil eden üç ortaokul rastgele bir şekilde seçilmiş, bunlardan yine rastgele seçilen on iki şubenin 5,6 ve 7. ve 8 . sınıflarında öğrenim gören 411 ortaokul öğrencisi çalışma grubuna dâhil edilmiştir. Araştırmaya katılan öğrencilerin $\% 46$ 'sı kız, \%54'ü erkek öğrencidir. Ayrıca katılımcıların \% 24,6 's1 5. sinıf, $\% 24,1$ 'i altınc1, $\% 26,3$ 'ü yedinci ve $\% 25,1$ 'i de sekizinci sınıfta öğrenim görmektedir. Seçtikleri konuyla ilgili bir bilgilendirici metin yazmaları istenmesine rağmen öyküleyici metin yazan ve Suriyeli olduğu için herhangi bir metin yazmayan on iki öğrencinin metni değerlendirmeye alınmamış ve çalışma grubuna dâhil edilmemiştir.

\subsection{Veri Toplama Arac1}

Ortaokul öğrencilerinin bilgilendirici yazma düzeylerini açığa çıkarmayı amaçlayan bu araştırmada veri toplama aracı olarak "Kişisel Bilgi Formu" ve Müldür (2017) tarafindan hazırlanan "Bilgilendirici Metin Yazma Değerlendirme Formu" ölçme aracı olarak kullanılmıştır. Bilgilendirici Metin Yazma Değerlendirme Formu; ana fikir/odak noktası, yardımcı fikirler ve fikirleri destekleme, planlama ve tutarlık, dil ve üslup, yazım ve noktalama, sunum olmak üzere yedi maddeden oluşmaktadır. Formda yer alan ölçütler 1=kötü, 2=yetersiz, 3=orta, 4=iyi, 5=çok iyi şeklinde puanlandırılmıştır. Bir öğrencinin bu formdan alabileceği en düşük puan 7, en yüksek puan da 35'tir.

Öğrencilere farklı yapılarda bilgilendirici metinler oluşturabilecekleri konular sunulmuştur. Öğrencilerden "Hayalinizdeki okulu tanıtan bir metin yazınız.", "Size göre ideal bir dostta olması gereken özellikleri anlatan bir metin yazınız.", "Cep telefonlarının olumlu ya da olumsuz etkilerini anlatan bir metin yazınız." "Bir mucit olduğunuzu düşünün. İnsanlığın bir problemini çözecek bir icadınız var. İcadınız nedir, bu icat insanlığın hangi problemini nasıl çözer, bunu anlatan bir metin yazınız." konularından birini seçerek bilgilendirici (açıklayıcı) bir metin oluşturmaları istenmiştir. Öğrenci metinleri, veri toplama aracı olarak kullanılan forma göre değerlendirilmiştir.

Değerlendirme formunun güvenirliğini tespit etmek için veri toplama aracının örneklem üzerindeki güvenirlik katsayısı hesaplanmıştır. Öğrenci metinlerine göre Bilgilendirici Metin Yazma Değerlendirme Formu aracının güvenirlik katsayısı .94 bulunmuştur. Ayrıca kodlayıcılar arası uyum yöntemine başvurulmuştur. Öğrenci metinleri iki uzman tarafından bağımsız şekilde puanlanmıştır. Pearson Korelasyon analizi aracıllğıyla puanlayıcıların verdiğgi puanlar arasındaki korelasyon katsayısına bakılmıştır. İki puanlayıcı arasındaki korelasyon katsayısı 0,83 olarak hesaplanmıştır. Çıkan bu sonuç 0,70 'in üzerinde olduğu için değerlendirme formunun güvenilir olduğu söylenebilir.

\subsection{Verilerin Analizi}

Araştırmada ortaokul öğrencilerinin Bilgilendirici Metin Yazma Değerlendirme Formu'nun her bir maddesinden ve toplamından aldıkları puanları değerlendirmek için betimsel istatistikler (frekans, aritmetik ortalama ve standart sapma) kullanılmıştır. Öğrencilerin bilgilendirici yazma puanlarının cinsiyete göre anlamlılık gösterip göstermediğini belirlemek amacıyla bağımsız örneklemler $t$ testi, sınıf değişkenine göre anlamlılık gösterip göstermediğini belirlemek için tek yönlü varyans analizi (ANOVA) ve Dunnett $C$ testi kullanılmıştır. Grup varyansları eşit olmadığı için Dunnett $\mathrm{C}$ testi uygulanmıştır.

\section{Bulgular ve Yorumlar}

$\mathrm{Bu}$ bölümde araştırmanın alt problemleri bağlamında elde edilen bulgulara ve yorumlara yer verilmiştir.

\section{1. Öğrencilerin Bilgilendirici (Açıklayıcı) Metin Yazma Beceri Düzeyleri}

Araştırmaya katılan 411 öğrencinin Bilgilendirici Yazma Değerlendirme Formu'ndaki her bir ölçüt ve toplam puanlarına ilişkin betimsel istatistikler Tablo 1'de sunulmuştur. 
Tablo 1. Öğrencilerin Bilgilendirici Metin Yazma Düzeylerine İlişkin Betimsel İstatistikler

\begin{tabular}{lllll}
\hline $\begin{array}{l}\text { Değerlendirme Formu } \\
\text { Unsurları }\end{array}$ & $\min$ & $\max$ & $\bar{x}$ & ss \\
\hline Ana fikir/odak noktası & 1,00 & 4,00 & 1,78 & 0,77 \\
\hline $\begin{array}{l}\text { Yardımcı fikirler ve } \\
\text { fikirleri destekleme }\end{array}$ & 1,00 & 4,00 & 1,50 & 0,62 \\
\hline Planlama ve Tutarlılık & 1,00 & 4,00 & 1,72 & 0,73 \\
\hline Dil ve Üslup & 1,00 & 4,00 & 1,70 & 0,74 \\
\hline Bağdaşılık & 1,00 & 4,00 & 1,73 & 0,75 \\
\hline Yazım ve Noktalama & 1,00 & 4,00 & 1,47 & 0,73 \\
\hline $\begin{array}{l}\text { Sayfa Düzeni, Yazı, } \\
\text { Paragraf Boşluğu }\end{array}$ & 1,00 & 4,00 & 1,54 & 0,73 \\
\hline Toplam & 7 & 25 & 11,44 & 4,38 \\
\hline
\end{tabular}

Not: Bilgilendirici Metin Yazma Değerlendirme Formu'nda yer alan her bir ölçütten alınabilecek en düşük puan 1 , en yüksek puan ise 5 'tir. Formun tamamından alınabilecek en yüksek puan $35^{\prime}$ tir.

Tablo 1 incelendiğinde 411 öğrencinin bilgilendirici metin yazma ölçütlerine göre ana fikir $(\bar{x}=1,78$, ss=0,77), bağdaşıklık ( $\bar{x}=1,73, \mathrm{ss}=0,75)$, planlama ve tutarlık $(\bar{x}=1,72$, $\mathrm{ss}=0,73)$, dil ve üslup $(\bar{x}=1,70, \mathrm{ss}=0,74)$, sayfa düzeni, yazı, paragraf boşluğu $(\bar{x}=1,54, \mathrm{ss}=0,73)$; yardımcı fikirler ve fikirleri destekleme $(\bar{x}=1,50, \mathrm{ss}=0,62)$; yazım ve noktalama $(\bar{x}=1,47, \quad$ ss $=0,73)$ hususlarında "kötü" ve "yetersiz" düzeyler arasında puanlar aldıkları görülmektedir. Öğrencilerin toplam puan ortalamasının da 11,44 olduğu görülmektedir. Buna göre katılımcıların bilgilendirici metin yazma becerilerinin "yetersiz" düzeyde oldukları söylenebilir.

Her bir ölçüt için kötü ve yetersiz olduklarını ortaya koyan nitelikler incelendiğinde bir ana fikir belirleme, odak noktası oluşturma açısından öğrenci metinlerinin ana fikrin açık olmaması veya zayıf olması, bir odak noktasının seçilerek konunun sınırlandırılmaması niteliklerini taşıdığı tespit edilmiştir. Yardımcı fikirleri ve fikirleri destekleme açısından seçilen konuya uygun fikirlerin gelişigüzel bir şekilde âdeta peş peşe ve liste özelliği gösterecek şekilde sıralanması ve fikirlerin düşünceyi geliştirme yollarıyla geliştirilmemesidir. Planlama ve tutarlık açısından metin yapısına uygun bir metin üretilmemesi, metinler arası bölümler, birimler (başlık, giriş, gelişme, sonuç, paragraf vb.) arasında kopuklukların, çelişkilerin olması gibi niteliklerdir. Dil ve üslup açısından metindeki açıklık ve anlaşılırlığın zayıf olması, metinde ikna edici, akıcı olmaması, cümle yapılarının son derece sınırlı olması ve daha çok basit yapılı cümlelerin kullanılması gibi niteliklerdir. Öğrenci metinleri, uzunlukları göz önünde bulundurularak incelendiğinde metnin anlaşılırlı̆̆ını etkileyecek düzeyde bağdaşıklık unsurlarının kullanımına ilişkin fazlaca hata taşımaktadır. Bilgilendirici metin yapılarını kuvvetlendiren bağdaşıklık unsurlarına yani bağlama ögelerine de yeteri kadar önem verilmediği tespit edilmiştir. Yazım ve noktalama açısından metin uzunlukları, öğrencilerin yaş ve seviyeleri göz önünde bulundurularak yazım ve noktalama açısından da metinlerde fazlaca hata görülmesi ve bunların metnin anlaşılırlığını zayıflatması niteliği taşımaktadır. Metinler sayfa düzeni, yazı ve paragraf boşlukları gibi unsurlarında da zayıf olma niteliği göstermektedir. Elde edilen bu bulgular, katılımcıların bilgilendirici metin yazma konusunda ciddi sıkıntılarının olduğunu göstermektedir.

\section{2. Öğrencilerin Cinsiyete Göre Bilgilendirici (Açıklayıcı) Metin Yazma Becerileri}

Öğrencilerin cinsiyetlerine göre bilgilendirici metin yazma becerileri arasında fark olup olmadığını belirlemek amacıyla yapılan bağımsız örneklemler t testi sonuçları Tablo 2'de sunulmuştur.

Tablo 2. Öğrencilerin Cinsiyetine Göre Bilgilendirici Metin Yazma Becerilerine İlişkin Bağımsız Örneklemler T Testi Sonuçları

\begin{tabular}{lcccccc}
\hline Cinsiyet & $\mathrm{N}$ & $\bar{x}$ & $\mathrm{ss}$ & $\mathrm{t}$ & $\mathrm{sd}$ & $\mathrm{p}$ \\
\hline K1z & 189 & 12,76 & 4,46 & 5,87 & 409 & 0,00 \\
\hline Erkek & 222 & 10,31 & 3,98 & & & \\
\hline
\end{tabular}

Öğrencilerin cinsiyetlerine göre bilgilendirici metin yazma becerileri arasında fark olup olmadığını gösteren Tablo 2'deki analiz sonucu incelendiğinde k1z ve erkek öğrencilerin bilgilendirici metin yazma becerileri arasındaki farkın istatistiksel olarak anlamlı olduğu görülmektedir [ $\mathrm{t}$ $(409)=5,87 ; \mathrm{p}<.01]$. Buna göre k1z öğrencilerin erkek öğrencilere kıyasla bilgilendirici metin yazma becerisi açısından daha başarılı oldukları söylenebilir.

\section{3. Öğrencilerin Sınıf Düzeyine Göre Bilgilendirici (Açıklayıcı) Metin Yazma Becerileri}

Öğrencilerin sınıf düzeyine göre bilgilendirici metin yazma puanlarına ilişkin betimsel istatistik ve tek yönlü varyans analizi (ANOVA) sonuçları Tablo 3'te sunulmuştur.

Tablo 3. Öğrencilerin Sınıf Düzeyine Göre Bilgilendirici Metin Yazma Puanlarına İlişkin Betimsel İstatistik ve Tek Yönlü Varyans Analizi Sonuçları

\begin{tabular}{lcccccl}
\hline $\begin{array}{l}\text { Sinıf } \\
\text { Düzeyi }\end{array}$ & $\mathrm{N}$ & $\bar{x}$ & ss & F & p & Anlaml1 Fark \\
\hline A. 5. Sinıf & 101 & 9,06 & 2,97 & 26,35 & 0,05 & $\begin{array}{l}\text { A-B, A-C, A- } \\
\text { D }\end{array}$ \\
\hline B. 6. Sinıf & 99 & 11,43 & 3,74 & & $\begin{array}{l}\text { D-A, D-B, D- } \\
\text { C }\end{array}$ \\
\hline C. 7. Sinıf & 108 & 11,35 & 4,31 & & & \\
\hline D. 8. Sinıf & 103 & 13,85 & 4,89 & & & \\
\hline
\end{tabular}

Tablo 3'te görüldüğü gibi öğrencilerin sınıf düzeyine göre bilgilendirici metin yazma puanları arasında anlamlı fark tespit edilmiştir [Welch $\mathrm{F}(3-223,14)=26,35 ; \mathrm{P}<0,05]$. $\mathrm{Bu}$ farkın hangi gruplar arasında olduğunu belirlemek amacı Dunnett $\mathrm{C}$ testi uygulanmıştır. Beşinci sınıf öğrencilerinin $(\bar{x}=9,06, \mathrm{ss}=2,97)$ diğer sinıflarda öğrenim gören öğrencilere kıyasla bilgilendirici metin yazma puanlarının anlamlı düzeyde düşük olduğu tespit edilmiştir. Altıncı sınıf $(\bar{x}=11,43$, ss $=3,74)$ ve yedinci $\sin 1 \mathrm{f}(\bar{x}=11,35$, ss $=4,31)$ öğrencilerinin bilgilendirici yazma puanları arasında anlamlı bir farklılık görülmemiştir. Ayrıca sekizinci sınıf öğrencilerin $(\bar{x}=13,85, \mathrm{ss}=4,89)$ diğer sınıflarda öğrenim gören öğrencilere kıyasla bilgilendirici metin yazma puanlarının anlamlı düzeyde yüksek olduğu tespit edilmiştir. Elde edilen bu sonuçlara göre beşinci sınıf öğrencilerinin bilgilendirici metin yazma becerilerinin diğer sınıf düzeylerine kıyasla daha zayıf olduğu söylenebilir. Sekizinci sınıf öğrencilerinin de bilgilendirici metin yazma becerisi açısından diğer sınıf düzeylerine kıyasla daha başarılı olduğu söylenebilir. 


\section{Tartışma, Sonuç ve Öneriler}

$\mathrm{Bu}$ çalışmada ortaokul öğrencilerinin bilgilendirici metin yazma düzeyleri tespit edilmiş̧; cinsiyet ve sınıf düzeyi değişkenlerine göre incelenmiştir. Araştırma sonucunda öğrencilerin bilgilendirici yazma becerilerinin "yetersiz" olduğu görülmektedir. Elde edilen bu sonuç daha önce yapılan çalışmalarla da örtüşmektedir. Örneğin bilgilendirici metinlere göre yap1 ve üretim açısından daha kolay olan öyküleyici metin yazma açısından bakıldığında yapılan araştırmalar öğrencilerin öyküleyici metin yazma açısından dahi öğrencilerin orta seviyenin altında olduğunu ortaya koymaktadır (Coşkun, 2005; Kaynaş, 2014; Yılmaz, 2008). Öğrencilerin ikna edici yazma durumları açısından bakıldığında da benzer bir durumla karşılaşılmaktadır. Kaptan (2015) ve Kan ve Erbaş (2017), beşinci sınıf öğrencilerinin ikna edici metinlerini incelediği çalışmalarında öğrencilerin istenilen seviyede olmadığını, öğrencilerin aldıkları toplam puanların ortalamanın altında olduğunu tespit etmiş̧tir.

Mevcut araştırmada öğrencilerin Bilgilendirici Metin Yazma Değerlendirme Formu'nda yer alan alt ölçütler açısından da kötü ve yetersiz düzeyde oldukları görülmüştür. Formda yer alan kötü ve yetersiz niteliği taşıyan nitelikler incelendiğinde öğrenci metinlerinde ana fikrin açık olmaması veya zayıf olmas1, konunun sinırlandırılmaması, yardımcı fikirlerin gelişigüzel bir şekilde sıralanması, fikirlerin düşünceyi geliştirme yolları ile desteklenmemesi, metin yapısına uygun metin üretilmemesi, metinler arası bölümler, birimler (başlık, giriş, gelişme, sonuç, paragraf vb.) arasında kopuklukların olması gibi içeriksel ve yapısal sorunlara rastlanmaktadır. Ayrıca metinlerde dil ve üslup açısından da metindeki açıklık ve anlaşılırlığın zayıf olması, ikna ediciliğin ve akıcılığın olmaması, cümle yapılarının son derece sınırlı olması ve daha çok basit yapılı cümlelerin kullanılması gibi sorunların olduğu görülmüştür. Öğrencilerin bağdaşıklık unsurlarına ilişkin kullanımlarında da fazlaca hataya rastlanmış olup bilgilendirici metin yapılarını kuvvetlendiren bağlama ögelerine de yeteri kadar önem vermedikleri belirlenmiștir. Yazım ve noktalama, sayfa düzeni, yazı gibi unsurlar açısından da metinlerin zayıf olduğu tespit edilmiştir.

Bilgilendirici metin unsurlarına ilişkin elde edilen bu sonuçlar da daha önce yapılan çalışmalarla örtüşmektedir. Örneğin Ülper (2011) öğrencilerin bilgilendirici metinlerini tutarlık bağlamında incelediği araştırması kapsamında sekizinci sınıf öğrencilerinin bilgilendirici bir metindeki tutarlığı sağlayabilmek için yerine getirilmesi gereken birçok metinsel eylemi yerine getiremediklerini tespit etmiştir. Örneğin konu birliğini sağlama, metnin bölümlerini (girişi gelişme, sonuç) bağlama ve bununla ilişkili olarak da konu birliğini sağlama, bağdaşıklık araçlarını kullanma gibi konularda eksiklerinin olduğunu belirlemiştir. Sallabaş (2007) beşinci sınıfların yazılı anlatım becerilerini incelediği araştırmasında öğrencilerin daha çok yazının giriş ve sonuç cümlelerini seçme, yazılarında söz varlığından yararlanma, uygun ifadeleri kullanarak destekleyici ve açıklayıcı örnekler verme, karşılaştırmalar, tanımlamalar yapma, önem belirten ifadeleri kullanma, duygu düşünce ve hayallerini anlatan yazılar yazma gibi konularda zorlandıklarını belirlemiştir. Çelik (2010) sekizinci sınıf öğrencileri üzerinde yürüttüğü çalışması sonucunda öğrencilerin Türkçenin söz varlığından yararlanarak anlatımı zenginleştirme, olayları ve bilgileri sıralayarak anlatma, sebep-sonuç, amaç-sonuç iliş̧isi kurma, konunun ve türün özelliklerine uygun giriş yapma, yazıyı uygun ifadelerle bitirme, düşünceyi geliştirme gibi hususlarda eksikliklerinin olduğunu tespit etmiştir. Öğrencilerin dil ve üslup, yazım ve noktalama, yazı gibi konularda yaşadıkları sıkıntılar da daha önce yapılan çalışmaların sonuçları ile örtüşmektedir (Alkan, 2007; Büyükikiz, 2007; Kırbaş, 2006). Söz konusu bu araştırmalar, mevcut araştırmayı destekleyici bir nitelik taşımakta ve öğrencilerin sorunlarını desteklemektedir.

Öğrencilerin diğer çalışmalardakine benzer şekilde bilgilendirici metin yazma açısından yetersiz düzeyde olmalarının pek çok unsurla ilişsisi olabilir. Elde edilen bu sonucun öğrencilerin söylem bilgisi farkındalıklarının olmaması, öğrencilerin bilişsel ve bellekle ilgili sıkıntıları, öğrencilere nitelikli bir yazma eğitiminin verilmemesi gibi unsurlarla ilişkili olabileceği düşünülmektedir.

Öğrencilerin söylem bilgisi farkındalıklarının olmamasının öğrencilerin bilgilendirici metin yazma becerisinin zayıf olmasındaki sebeplerden biri olduğu düşünülebilir. Söylem bilgisinin okuduğunu anlama ve yazma başarısı ile ilişsili olduğunu gösteren çalışmalar (Englert ve Thomas, 1987) olmakla birlikte anlama becerisini oluşturan okuma becerisi açısından bakıldığında dahi ülkemizdeki öğrencilerin bilgilendirici metin unsurların belirleme konusunda zayıf olduğu görülmektedir. Uğur (2017) araştırmasında yedinci sınıf öğrencilerinden büyük çoğunluğunun bilgilendirici metinlerin konusunu, yazarın yazma amacını, yazarın bakış açısını, metnin ana düşüncesini, yardımcı düşüncesini, belirleyemediklerini tespit etmiştir. Ayrıca öğrencilerin büyük çoğunluğunun tanım, karşılaştırma, şart, açıklama, benzetme gibi ifadeleri de tespit edemedikleri görülmüştür. Söz konusu bu araştırmayla öğrencilerin bilgilendirici bir metni meydana getiren çeşitli yapısal unsurları belirlemede oldukça başarısız oldukları sonucuna ulaşmıştır (Uğur, 2017). Bu açıdan bakıldığında, okuma anlamında dahi bilgilendirici metin yapısı farkındalığı olmayan öğrencilerin yazma açısından daha da zayıf olma durumu söz konusudur. Çünkü henüz mevcut bir metindeki yapı unsurlarını dahi tespit edemeyen öğrencilerin, üretimsel dil becerilerinden biri olan yazma becerisinde daha da zorlanmaları olasıdır.

Öğrencilerin bilgilendirici metin yapısı farkındalı̆ı̆ının az olmasına sebep olan nedenlerin de ögrencilerin bu anlamdaki zayıflığına sebep olduğu düşünülebilir. İlgili literatür bağlamında değinilen öğrencilerin küçük yaşlardan itibaren daha çok öyküleyici metin yapıları ile karşılaşması, bilgilendirici metin yapılarına aşina olmaması, okullarda bilgilendirici metin yapıları üzerinde yeterince durulmaması gibi sorunların (Armbruster vd., 1987; Duke, 2000; Hall vd., 2005; Taylor \& Beach, 1984) da ögrencilerin bilgilendirici metin yapısı farkındalığının az olmasına sebep olduğu söylenebilir. $\mathrm{Bu}$ nedenle söz konusu sorunlardan kaynaklanarak öğrencilerin bilgilendirici metin yapısı hakkındaki söylem bilgisi eksikliğinin onların bilgilendirici metin yazma konusunda sorunlar yaşamalarına sebep olduğu düşünülebilir.

Öğrencilerin bilişsel ve bellekle ilgili sıkıntılarının da bilgilendirici metin yazma becerilerini etkileyebileceği ve onların sorunlar yaşamalarına sebep olabileceği düşünülebilir. Yazma becerisi, öğrencilerin bilişsel süreçleri ile bağlantılıdır. Öğrencilerin mevcut sorunlar yaşamalarının bellekle bağlantılı olan bilişsel süreçlerle ilişkisi olduğu da 
düşünülebilir. Bereiter ve Scarmadalia’ya (1984) göre metin yapısı belleği olmadığında yazarlar üç tür sorunla karşı karşıya kalabilirler: daha önce söylediklerini tekrar etme, metni erkenden bitirme ve metin içerisindeki ilgisizlikler (Aktaran, Thomas vd., 1987). Mevcut araştırmada da öğrenci metinlerinde bu tür sıkıntılara sık sık rastlanmış; fikirlerin peş peşe gelişigüzel bir şekilde sıralanması, kimi zaman yinelenmesi, özet şeklini almış kısa metinler yazılması veya metinlerin tamamlanmaması, metin bölümleri, birimleri arasında kopuklukların, ilgisizliklerin görülmesi gibi sorunlar tespit edilmiştir. Bu nedenle öğrencilerin bellekle ilgili benzeri sorunlar yaşamalarının bu tür sorunlara sebep olduğu düşünülebilir.

Öğrencilerin bilgilendirici metin yazma becerilerinin zayıf olmasında öğrencilere verilen yazma eğitiminin niteliğinin de etkili olabileceği düşünülmektedir. Türlü sebeplerden dolayı öğrencilere nitelikli bir şekilde yazma eğitimi verilememesinin de bilgilendirici metin yazma becerisini zayıflattığı düşünülebilir. Süreç ve süreç-tür odaklı yazma eğitimlerinin öğrencilerin bilgilendirici metin yazma becerisi üzerinde etkisi olduğunu gösteren araştırmalar (Örn. Ülper, 2008; Graham, Harris \& Mason, 2005) mevcut olmakla birlikte ülkemizdeki yazma eğitiminin niteliğinin bu bağlamda olmadığı söylenebilir.

Mevcut çalışmanın uygulandığı sınıflarda öğrencilerden metinlerini öncesinde planlayabilecekleri söylenmesine rağmen birkaç öğrenci dışında yazma öncesinde hazırlık yapan bir öğrenciye rastlanmamıştır. $\mathrm{Bu}$ durum okullarımızda nitelikli bir yazma eğitimi verilip verilmediğine ilişkin şüpheler uyandırmaktadır. Dolayısıyla nitelikli bir yazma eğitimi verilmemesinin, yazma eğitimi alanında da daha çok öyküleyici metinler üzerinde durulmasının öğrencilerin bilgilendirici metin yazma konusunda zayıf olmasına sebep olduğu düşünülebilir.

Mevcut araştırmada ortaokul öğrencilerinin bilgilendirici yazma puan ortalamalarında kızlarla erkekler arasında kızlar lehine istatistiksel olarak anlamlı bir farklılık elde edilmiştir. Cinsiyet değişkeninin yazma başarı açısından etkin olmadığını gösteren çalışmalar da mevcut olmakla birlikte (Çelik, 2010; Çoban, 2010) bu çalışmadan elde edilen sonuç kı öğrencilerin yazma konusunda daha başarılı olduğunu ortaya koyan farklı çalışmalarla örtüşmektedir (Arı, 2008; Arıc1 ve Ungan, 2008; Gökçe ve Sis, 2017; Kan ve Erbaş, 2017; Kaptan, 2015; Kaynaş, 2014; Seçkin, Arslan ve Ergenç, 2014; Ülper, 2011; Yaylacık, 2014). Elde edilen bu sonuçtan hareketle cinsiyet değişkeninin yazmada etkili olduğu söylenebilir. Ortaya çıkan bu durum, ergenlik döneminde kızlar ve erkeklerin bilişsel, duyuşsal farklılıklar yaşaması ile açıklanabilir. Kızların erkeklere göre daha çabuk olgunlaşması ve akademik çalışmalara daha çok yoğunlaşabilmesi, kızların yazma konusunda daha fazla motive olması elde edilen sonuçla ilişkilendirilebilir. Nitekim Troia, Harbaugh, Shankland, Wolbers ve Lawrence (2012) araştırmalarında cinsiyetin yazma performansını etkileyen önemli bir değişken olduğunu ortaya koymuştur. Pajares (2003) de alanyazın derlemesi niteliği taşıyan çalışmasında özellikle ortaokul seviyesinde kız öğrencilerin erkek öğrencilere kıyasla yazma motivasyonunun yüksek olduğunu ortaya koyan pek çok araştırmanın mevcudiyetine değinmektedir. Mevcut araştırmada cinsiyet değişkenine göre farklılık olmasına yönelik elde edilen sonucun Kaptan (2015), Kan ve Erbaş'ın (2017) belirttiği gibi kız öğrencilerin metnin içeriğinden ziyade yazım, noktalama, sayfa düzeni gibi mekanik unsurlarında daha başarılı olmasıyla ilişkili olabileceği de düşünülebilir.

Mevcut araştırmada ele alınan diğer bir değişken de sınıf düzeyi değişkenidir. Araştırmada öğrencilerin bilgilendirici metin yazma puan ortalamalarında farklılık tespit edilmiştir. Elde edilen bulgulara göre 5. sinıf öğrencilerinin bilgilendirici metin yazma becerileri açısından diğer sınıf düzeylerindeki $(6,7$ ve 8 . sinıflar $)$ öğrencilerle kıyaslandığında daha zayıf; 8. sınıf öğrencilerinin de daha başarılı; 6 ve 7. sınıf öğrencilerinin ise neredeyse aynı düzeyde olduğu görülmüştür. Yaş ilerledikçe öğrencilerin bilişsel becerileri de gelişmektedir ve planlama, fikir üretimi gibi bilişsel becerilerle ilişsili olan (Flower ve Hayes, 1981) yazma becerisinin de yaş ile birlikte gelişmesi de beklenen bir durumdur. Dolayısıyla bilişsel becerileri diğer kademelere kıyasla daha az gelişmiş olan 5. sınıf öğrencilerinin bilgilendirici metin yazma becerisi açısından zayıf; bilişsel becerileri diğer kademelere kıyasla daha fazla gelişmiş olan 8. sınıf öğrencilerinin ise bilgilendirici metin yazma açısından daha başarılı olmaları beklenen bir durumdur. Coşkun (2005) araştırmasında sekizinci sınıf öğrencilerinin beşinci sınıf öğrencilerine kıyasla metin elementlerini kullanma, tutarlı metin oluşturma açısından anlamlı düzeyde daha başarılı olduklarını tespit etmiştir. Mevcut araştırmada yedinci sınıf öğrencilerinin altıncı sınıf öğrencilerinden daha başarılı olması beklenirken öğrencilerin bilgilendirici metin yazma becerileri arasında anlamlı farklılığa rastlanmamıştır. Arı (2010) da araştırmasında yedinci sınıfların metnin biçimsel özellikleri ve paragraf, serim özellikleri açısından yedinci sınıf öğrencilerinin daha başarılı olduğunu tespit etmekle birlikte bazı değişkenler açısından (cümle, gelişme ve sonuç) özellikleri açısından altıncı sınıf öğrencilerinin yedinci sınıflardan daha başarılı olduğunu tespit etmiştir. Ayrıca iki sınıfın anlatım özelliği ortalamasının da aynı olduğunu tespit etmiştir. Elde edilen bu sonucun beklenmediğini, çünkü yedinci sınıf öğrencilerinin daha çok eğitim almış, yazma bakımından da daha deneyimli olmaları gerektiğini dile getirmiştir. Bu noktadan hareketle araştırmaya dâhil edilen öğrencilere verilen yazma eğitiminin niteliğinin de söz konusu sonuçlarda etkisi olduğu düşünülebilir.

Sonuç olarak bu araştırma çerçevesinde ortaokul öğrencilerinin bilgilendirici yazma becerilerinin yetersiz olduğu tespit edilmiştir. Bilgilendirici metni oluşturan alt unsurlar açısından da öğrencilerin kötü ve yetersiz düzeyde oldukları görülmüştür. Elde edilen bu sonucun detaylı bir şekilde tartışıldığı üzere öğrencilerin söylem bilgisi farkındalıklarının olmaması, öğrencilerin bilişsel ve bellekle ilgili sıkıntıları, öğrencilere nitelikli bir yazma eğitiminin verilmemesi gibi unsurlarla ilişkili olabileceği düşünülmektedir. Araştırma kapsamında kızların erkeklere oranla daha başarılı bilgilendirici metinler kaleme aldığı tespit edilmiştir. $\mathrm{Bu}$ sonucun ergenlikte cinsiyete göre değişebilen farklılıklar, kızların daha çabuk olgunlaşması, kızların yazma konusunda daha fazla motivasyona sahip olması, kızların metnin mekanik unsurlarında daha başarılı olması gibi unsurlarla ilişkili olabileceği düşünülmektedir. Son olarak araştırma sonucunda sınıf değişkenine göre de bir farklılık tespit edilmiştir. Ortaya çıkan bu sonucun okullarda verilen yazma eğitiminin niteliği ile ilgili olabileceği düşünülmektedir. Bu çerçevede şu önerilerde bulunulabilir: 
(i) Öğrencilere bilgilendirici metin yapı ve unsurlarına ilişkin farkındalık kazandırılmalı, öğrencilerin bilgilendirici metinlere yönelik söylem bilgileri artırilmalidir.

(ii) Öğrencilere daha nitelikli bir yazma eğitimi verilmelidir. $\mathrm{Bu}$ bağlamda öğrencilere hem süreç hem de tür odaklı bir yazma eğitiminin verilmesi gerektiği söylenebilir.

(iii) Yazma bağlamında öğrencilerin bilgilendirici metin yap1 farkındalıklarının hangi düzeyde olduğuna yönelik bir araştırma uygulanabilir.

(iv) Mevcut araştırmada öğrencilerden farklı metin yapılarından oluşan yazma konularından birinde yazmaları istenmiştir. . Öğrencilerin bilgilendirici metin yapılarının her birinde hangi düzeyde olduklarını tespit etmeye yönelik çalışmalar yapilabilir.

(v) Araştırmanın çalışma grubu, dört yüz on bir öğrenci ile sınırlıdır. Araştırma daha geniş bir hedef kitle üzerinde uygulanarak öğrencilerin bilgilendirici metin yazma düzeylerini ortaya çıkaracak farklı araştırmalar yapılabilir.

\section{Kaynakça}

Akyol, H. (1999). Bilgi vermeye dayalı metinler ve öğretimi. Çăgdaş Ĕ̆itim, 253(7), 7-13.

Akyol, H. (2010). Yeni programa uygun Türkçe öğretim yöntemleri. Ankara: Pegem Akademi.

Alkan, Z. N. (2007). Illköğretim beşinci sınıf öğrencilerinin yazılı anlatım hataları. Yüksek Lisans Tezi, Osmangazi Üniversitesi Sosyal Bilimler Enstitüsü, Eskişehir.

Arı, G. (2008). Öğrencilerin hikâye edici metinlerinin çözümleyici puanlama yönergesine göre değerlendirilmesi (6. ve 7. sinıf örneği). Doktora Tezi, Marmara Üniversitesi Eğitim Bilimleri Enstitüsü, İstanbul.

Arıc1, A. F., \& Ungan, S. (2008). İlköğretim ikinci kademe öğrencilerinin yazılı anlatım çalışmalarının bazı yönlerden değerlendirilmesi. Dumlupınar Üniversitesi Sosyal Bilimler Dergisi, (20), 317-328.

Armbruster, B. B., Anderson, T. H., \& Ostertag, J. (1987). Does text structure/summarization instruction facilitate learning from expository text?.Reading Research Quarterly, 22(3), 331-346.

Best, R. M., Floyd, R. G., \& Mcnamara, D. S. (2008). Differential competencies contributing to children's comprehension of narrative and expository texts. Reading psychology, 29(2), 137-164.

Bohaty, J. J. (2015). The efects of expository text structure instruction on the reading outcomes of 4th and 5th graders experiencing reading difculties. Doctoral dissertation, University of Nebraska, Lincoln.

Büyükikiz, K. K. (2007). İlköğretim 8. sınıf öğrencilerinin yazılı anlatım becerilerinin söz dizimi ve anlatım bozukluğu açısından değerlendirilmesi. Yüksek Lisans
Tezi, Gazi Üniversitesi Eğitim Bilimleri Enstitüsü, Ankara.

Can, A. (2017). SPSS ile Bilimsel araştırma sürecinde nicel veri analizi. Ankara: Pegem Akademi.

Coşkun, E. (2005). İköğretim öğrencilerinin öyküleyici anlatımlarında bağdaşıklık, tutarlılık ve metin elementleri. Doktora Tezi, Gazi Üniversitesi Eğitim Bilimleri Enstitüsü, Ankara.

Coşkun, E. (2013). Türkçe öğretiminde metin bilgisi. A. Kırkkılıç \& A. Akyol (Ed.), Illköğretimde Türkçe ögretimi içinde (s. 231-284). Ankara: Pegem Akademi.

Çeçen, M. A. (2011). Yedinci sınıf öğrencilerinin öyküleyici yazılarında tutarlılık. Türkiye Sosyal Araştırmalar Dergisi, 15(2), 1-20.

Çelik, M. E. (2010). İlköğretim sekizinci sınıf öğrencilerinin bilgilendirici metin yazma kazanımlarına ulaşma düzeyleri. Yüksek Lisans Tezi, Ondokuz Mayıs Üniversitesi Eğitim Bilimleri Enstitüsü, Samsun.

Çoban, A. (2010). Illkögretim 7. sınıf öğrencilerinin oluşturdukları öyküleyici metinlerin bağdaşıklık ve tutarlılık ölçütlerine göre değerlendirilmesi. Yüksek Lisans Tezi, Erciyes Üniversitesi Eğitim Bilimleri Enstitüsü, Kayseri.

De Beaugrande, R. A., \& Dressler, W. U. (1986). Introduction to text linguistic. London: Longman Group Company.

Duke, N. K. (2000). 3.6 minutes per day: The scarcity of informational texts in first grade. Reading Research Quarterly, 35(2), 202-224.

Duke, N. K. (2004). The case for informational text. Educational Leadership, 61(6), 40-45.

Englert, C. S., \& Hiebert, E. H. (1984). Children's developing awareness of text structures in expository materials. Journal of educational psychology, 76(1), 65.

Englert, C. S., \& Thomas, C. C. (1987). Sensitivity to text structure in reading and writing: A comparison between learning disabled and non-learning disabled students. Learning Disability Quarterly, 10(2), 93-105.

Flower, L., \& Hayes, J. R. (1981). A cognitive process theory of writing. College Composition and Communication, 32(4), 365-387.

Fraenkel, J. R., Wallen, N. E. (2009). How to design and evaluate research in education. New York: McGraw-Hill Humanities/Social Sciences/Languages.

Gökçe, B., \& Sis, N. (2017). Sekizinci sınıf öğrencilerinin tartışmacı metin yazma becerilerinin çeşitli değişkenler açısından incelenmesi. International Journal of Language Academy 5(8), 143-168.

Graham, S., Harris, K. R., \& Mason, L. (2005). Improving the writing performance, knowledge, and self-efficacy of struggling young writers: The effects of self-regulated strategy development. Contemporary Educational Psychology, 30(2), 207-241.

Günay, V. D. (2007). Metin bilgisi. İstanbul: Multilingual. 
Güneş, F. (2007). Türkçe öğretimi ve zihinsel yapılandırma. Ankara: Pegem Akademi.

Hall, K. M., \& Sabey, B. L. (2007). Focus on the facts: Using informational texts effectively in early elementary classrooms. Early Childhood Education Journal, 35(3), 261-268.

Hall, K. M., Sabey, B. L., \& McClellan, M. (2005). Expository text comprehension: Helping primary-grade teachers use expository texts to full advantage. Reading Psychology, 26(3), 211-234.

Hall-Mills, S., \& Apel, K. (2012). Narrative and expository writing of adolescents with language-learning disabilities: A pilot study. Communication Disorders Quarterly, 34(3), 135-143.

İpek Eğilmez, N., \& Berber, Z. T. (2017). Ortaokul beşinci sınıf öğrencilerin hikâye yazma becerileri. Ana Dili Eğitimi Dergisi, 5(2), 165-188.

Kan, M. O., \& Erbaş, A. (2017). Beşinci sınıf öğrencilerinin ikna edici yazma becerilerinin çeşitli değişkenler açısından incelenmesi. Insan ve Toplum Bilimleri Araştırmaları Dergisi-Journal of the Human and Social Science Researches, 6(5), 2228-2246.

Kaptan, A. (2015). Illkögrretim beşinci sınıf öğrencilerinin ikna edici yazma beceri düzeylerinin incelenmesi. Yüksek Lisans Tezi, Eskişehir Osmangazi Üniversitesi Eğitim Bilimleri Enstitüsü, Eskişehir.

Karasar, N. (2008). Bilimsel araştırma yöntemi. Ankara: Nobel Yayın Dağıtım.

Kaynaş, E. (2014). Beşinci sınıf öğrencilerinin öyküleyici metin yazma becerilerinin değerlendirilmesi. Yüksek lisans tezi, Eskişehir Osmangazi Üniversitesi Eğitim Bilimleri Enstitüsü, Eskişehir.

Kılıç, B. (2012). İlköğretim yedinci sınıf öğrencilerinin yazdıklarl öyküleyici metinler üzerine bir inceleme. Yüksek lisans tezi, Necmettin Erbakan Üniversitesi Eğitim Bilimleri Enstitüsü, Konya.

Kıran, Z., \& Eziler Kıran A. (2003). Yazınsal okuma süreçleri. Ankara: Seçkin.

Kırbaş, A. (2006). Ilköğretim sekizinci sınıf öğrencilerinin yazılı anlatım becerilerinin değerlendirilmesi. Yüksek Lisans Tezi, Atatürk Üniversitesi Sosyal Bilimler Enstitüsü, Erzurum.

McGee, L. M., \& Richgels, D. J. (1985). Teaching expository text structure to elementary students. The Reading Teacher, 38(8), 739-748.

MEB (2016). Millî eğitim istatistikleri örgün eğitim. Ankara.

MEB (2018). Türkçe dersi (1-8. Sinıflar) ögretim programı. Ankara.

Meyer, B. J. F. (1975). The organization of prose and its effects on memory. Amsterdam: North-Holland.

Meyer, B. J., \& Freedle, R. O. (1984). Effects of discourse type on recall. American Educational Research Journal, 21(1), 121-143.

Müldür, M. (2017). Öz düzenlemeye dayall yazma ĕgitiminin ortaokul ögrencilerinin bilgilendirici metin yazma becerisine, yazmaya yönelik öz düzenleme becerisine ve yazma öz yeterlik algisina etkisi. Doktora Tezi, Gazi Üniversitesi Eğitim Bilimleri Enstitüsü, Ankara.

Nelson, N. W., Bahr, C. M., \& Van Meter, A. M. (2004). Writing process instruction and computers: Making connections and building language. Baltimore: Paul $\mathrm{H}$. Brookes.

Özmen, E. R. (2011). Bir metin yapısı örneği: evrensel dünya problemlerine ilişkin problem çözüm yapısı. Mustafa Kemal Üniversitesi Sosyal Bilimler Enstitüsü Dergisi, 8(16), 49-62.

Pajares, F. (2003). Self-efficacy beliefs, motivation, and achievement in writing: A review of the literature. Reading \&Writing Quarterly, 19(2), 139-158.

Piccolo, J. A. (1987). Expository text structure: Teaching and learning strategies. The Reading Teacher, 40(9), 838847.

Sallabaş, M. E. (2007). Ilköğretim beşinci sınıf ögrencilerinin kendini yazll olarak ifade etme kazanımlarına ulaşma düzeyi. Yüksek Lisans Tezi, Gazi Üniversitesi Eğitim Bilimleri Enstitüsü, Ankara.

Seçkin, P., Arslan, N., \& Ergenç, S. (2014). Bağdaşıklık ve tutarlılık bakımından lise ve üniversite öğrencilerinin yazılı anlatım becerileri. Uluslararası Türkçe Edebiyat Kültür Ĕgitim (TEKE) Dergisi, 3(1), 340-353.

Şahin, A. (2013). The effect of text types on reading comprehension. Online Submission, 3(2), 57-67.

Tansel, F. A. (1978). İyi ve doğru yazma usûlleri. İstanbul: Kubbealt1.

Taylor, B. M., \& Beach, R. W. (1984). The effects of text structure instruction on middle-grade students' comprehension and production of expository text. Reading Research Quarterly, 19(2), 134-146.

Temizyürek, F. (2008). The impact of different types of texts on Turkish language reading comprehension at primary school grade eight students. Eurasian Journal of Educational Research (EJER), (30), 141-152.

Thomas, C. C., Englert, C. S., \& Gregg, S. (1987). An analysis of errors and strategies in the expository writing of learning disabled students. Remedial and Special education, 8(1), 21-30.

Tompkins, G. E. (2000). Teaching writing: Balancing process and product. New Jersey: Prentice Hall.

Troia, G. A., Harbaugh, A. G., Shankland, R. K., Wolbers, K. A., \& Lawrence, A. M. (2013). Relationships between writing motivation, writing activity, and writing performance: Effects of grade, sex, and ability. Reading and Writing, 26(1), 17-44.

Uğur, F. (2017). Ortaokul 7. sinıf öğrencilerinin bilgilendirici metin yapısı unsurlarını belirleme düzeyleri. Mustafa Kemal Üniversitesi Sosyal Bilimler Enstitüsü Dergisi, 14(39), 200-222.

Ülper, H. (2011). Öğrenci metinlerinin tutarlılık ölçütleri bağlamında değerlendirilmesi. Turkish Studies, 6(4), 849-863. 
Warriner, J. E. (1992). Warriner's English grammar and composition. Canada: Hold, Rinehart and Winston.

Williams, J. P. (2005). Instruction in reading comprehension for primary-grade students a focus on text structure. The Journal of Special Education, 39(1), 6-18.

Yaylacık, A. (2014). Üstün yetenekli beşinci sınıf ögrencilerinin öyküleyici metin yazma becerileri. Yüksek Lisans Tezi, Mustafa Kemal Üniversitesi Sosyal Bilimler Enstitüsü, Hatay.
Yıldırım, K., Yıldız, M., Ateş, S., \& Rasinski, T. (2010). İlköğretim beşinci sınıf Türk öğrencilerin metin türlerine göre okuduğunu ve dinlediğini anlama düzeyleri. Kuram ve Uygulamada Eğitim Bilimleri / Educational Sciences: Theory \& Practice, 10(3), 5-37.

Yılmaz, S. K. (2008). Ilkögretim altıncı sinıf öğrencilerinin öyküleyici metin yazma becerileri. Yüksek lisans tezi, Gazi Üniversitesi Eğitim Bilimleri Enstitüsü, Ankara. 
